\title{
SOURCES OF CONFLICT BETWEEN INTERNATIONAL LAW AND THE ANTITRUST LAWS
}

\author{
WILLIAM DWIGHT WHITHEY $\div$
}

\begin{abstract}
[Mr. Whitney, agrecing with Mr. Haight that a conflict exists. suggests reasons for it in American history. To avoid duplication. Mr. Whitney's article adopts the footnote support in Mr. Haight's.]
\end{abstract}

Adrericans are puzzled these days to hear from all sides that their foreign policy is not always popular abroad. Some resent this. Others, more prudent, seek the cause.

This political situation has its legal aspects, among which perhaps the most noteworthy is the adverse reaction abroad to the application of our antitrust laws to foreign corporations. On the one side, we have a series of actions by the Department of Justice, commanding apparently universal acquiescence in principle on the part of the American bar and endorsed in principle by uniformly favorable decisions of American judges. ${ }^{1}$ It has been assumed without question that the United States has jurisdiction over agreements governing trade and commerce in all countries of the world, whether in raw materials or finished products, whether in aluminum, petroleum, chemicals, or electrical products. Whether the agreement relates to trade in England. Egypt, or Ecuador, we have taken jurisdiction when some "effect" has been felt in the United States.

iMember, New York Bar; barrister-at-law, Inner Temple, London.

1. Notably, United States v. Aluninum Co. of America, 148 F.2d 410 (2d Cir. 1945); United States v. General Electric Co., 82 F. Supp. 753 (D.N.J. 1949); United States v. Imperial Chemical Industries, 100 F. Supp. 504 (S.D.N.Y. 1951), firal decree entered, 105 F. Supp. 215 (S.D.N.Y. 1952). The acquiescence by the bar is exemplified in the underlined portion of the following from Judge Learned Hand's opinion in the Aluminum case: "On the other hand, it is settled law-as Limited itself agrees-than any state may impose liabilities, even upon persons not within its allegiance, for conduct outside its borders which the state reprehends." 148 F.2d 416, 443 (2d Cir. 1945) (emphasis added). A notable feature of Judge Hand's statement is that it purports to be a statement of the law of nations. But no international authorities were tendered by Judge Hand to support his decision on international law. Only United States authorities vere cited: "Strassheim v. Daily, 221 U.S. 280, 284, 285, . . ; Lamar v. United States, 240 U.S. 60, 65, 66, . . ; Ford v. United States, 273 U.S. 593, 620, 621, . . ; Restatement of Conflict of Laws $\S 65$." The bribery in Strasshein and the false pretenses in Lamar were directed tuward lueal jurisdiction, and did not concern foreign nations at all. The ford case involved a conspiracy, to which Americans in San Francisco, as well as the British defendants aboard ship, were parties, to violate the prohibition laws by running intoxieating liquor into San Franciseu Bay. By treaty, Great Britain surrendered its right to object to the exercise of jurisdiction in cases of that character. The foreign nation concerned had thus expressly waived any question of international law. 
On the other side, but until now ignored in our courts, those antitrust activities have run up against the pride of foreign nations in their independent sovereignty, and against the principle of territoriality in international law. The classic authorities in international law are as absolute in their rejection of the sort of jurisdiction recently asserted by our prosecutors and courts as are the latter in its assertion. Here is a dangerous conflict that calls for reconciliation. ${ }^{2}$

We are concerned with jurisdiction; accordingly, the first requisite is to distinguish between jurisdiction over the person and jurisdiction over the subject-matter. A principal source of trouble has lain in the tendency to assume that if the former exists, the latter must follow. It has not always been realized that a court may have jurisdiction over the person of a defenclant, but that it lacks jurisdiction over a particular act of that defendant. In international law the guiding rule is that a State $A$ may assert personal jurisdiction over its own nationals for all purposes but over foreign nationals only for their acts within its territorial jurisdiction. State $A$, in asserting jurisdiction over its own nationals for their acts within the territory of State $B$, must, however, refrain from ordering them to act within that territory in violation of the laws there prevailing. And if State $A$ seeks to extend its jurisdiction over an act in State $B$ to a national of State $B$, this will normally be a breach both of the law and of the comity of nations. It is in effect a form of aggression-judicial aggression.

This was certainly the view of the Supreme Court in Amcrican Banana Company v. United Fruit Company. ${ }^{3}$ Coming to the Court on demurrer, the issue was whether or not to refuse jurisdiction over an alleged act of violence in Costa Rica by one American company against another. The decision was against jurisdiction. It has often been explained away on the ground that the defendant had procured the intervention of a file of soldiers, who committed the physical act, and that the case therefore stands only for the proposition that United States courts will not review the sovereign act of a foreign government. The Court, however, gave alternative grounds for its decision, of which only the second was the sovereign act of the Costa Rican government. The first ground was that the acts (whatever they were) took place outside the

2. That our concern is not academic has been demonstrated by the fate of that part of a decree entered by Judge Ryan in the important antitrust case of United States v. Imperial Chemical Industries, 100 F. Supp. 504 (S.D.N.Y. 1951). Judge Ryan cxercised jurisdiction to order transfer in England, by a British Company (ICI) to an American corporation (duPont), of title to British patents. ICI had previously granted an exclusive license to another British Company (British Nylon Spinners Co., Ltd.) of which one-half of the shares was owned by ICI and one-half by a third British company (Courtaulds) not a party to the litigation. Within a fortnight of Judge Ryan's order, performance of this order was enjoined by a British court (Judgment by Upjohn, J., in the Vacation Court, August 13, 1952), and the decision of Upjohn, J. was upheld by the court of appeal, British Nylon Spinners v. ICI, [1953] 1 Ch. 19.

3. 213 U.S. 347 (1909). 
United States, and that there was no jurisdiction if the Sherman Act was to be construed in harmony with international law."

The authority of the Banana case has been repeatedly recognized by the Supreme Court. 5 And where the Court has considered that the particular circumstances called for an application of extra-territorial jurisdiction, it has been careful to recognize that the Banana case was nonetheless authority both for the general rule and for the Sherman Act rule. The particular decisions were treated as special exceptions because of the compelling langunge of the particular statute under construction. ${ }^{\mathrm{B}}$

4. See the following famous passage in Justice Holmes" opinion, id. at 355-7: "In the first place the acts causing the damage were done, so far as appears, outside the jurisdiction of the United States, and within that of other states. It is surprising to hear it argued that they were governed by the act of Congress.

"[T] he general and almost universal rule is that the character of an act as lawful or unlawful must be determined wholly by the law of the country where the act is done. . . . For another jurisdiction, if it should happen to lay hold of the actor, to treat him according to its own notions rather than those of the place where he did the acts, not only would be unjust, but would be an interference with the authority of another sovereign, contrary to the comity of nations, which the other state concerned justly might resent. ...

". . . The foregoing considerations would lead in case of doubt, to a construction of any statute as intended to be confined in its operation and effect to the territorial limits over which the lawmaker has general and legitimate power. "All legislation is prima facie territorial.' [Citing cases]. Words having universal scope, such as 'every contract in restraint of trade,' 'every person who shall monopolize,' etc., will be talien as a matter of course to mean only every one subject to such legislation, not all that the legislator subsequently may be able to catch. In the case of the present statute [the Sherman Act] the improbability of the United States attempting to make acts done in Panama or Costa Rica criminal is obvious, yet the law begins by maling criminal the acts for which it gives a right to sue....

"For again, not only were the acts of the defendant in Panama or Costa Ries not within the Sherman Act, but they were not torts by the law of the place and therefore were not torts at all, however contrary to the ethical and economic postulates of that statute."

5. Foley Brothers v. Filardo, 336 U.S. 281, 287 (1949) ; Jaclssen v. S.S. Archimedes, 275 U.S. 463, 467 (1928); New York Central v. Chisholm, 269 U.S. 29, 32 (1925); Sandberg v. MacDonald, 248 U.S. 185, 195 (1918); Cubs Railroad Co. v. Crosby, 222 U.S. 473,478 (1912).

A group of cases involving shipping between two nations, of which the United States was one, are obviously not in conflict with the Banana case, for these were eases for concurrent jurisdiction as far as the courts of the two nations were concerned, and for settlement by treaty if the courts should disagree. United States v. Nord Deutscher Lloyd, 223 U.S. 512 (1912) (transportation between the United States and Germany, with particular reference to the American end); United States v. Pacific \& Arctic Ry. \& Navigation Co., $22 S$ U.S. 87 (1913) (transportation between the Linited States and Alaska or Canada); Thomsen v. Cayser, 243 U.S. 66 (1917) (transpurtation between the linited States and South Africa). Nor can United States v. Sisal Sales Curp., 274 C.S. $265^{\circ}$ (1927), be regarded as having overruled the Banana case, for the conspiracy in Sisal was entered into, and in large part to be performed within, the United States.

6. Strassheim v. Daily, 221 U.S. 280, 285 (1911) (bribery of a public officer; an interstate, not an international, case) ; United States v. Buwman, 260 U.S. 94, 97 (1922) (a criminal statute relating to conspiracy by citizens to defraud the Lnited States); 
The principle that American statutes are not to be construed to apply to acts abroad because Congress must be presumed to have intended not to violate international law, was not invented by Mr. Justice Holmes and his brethren in the Banana case. It goes back to the earliest volumes of the Supreme Court reports, in the opinions of such Justices as Marshall and Story. Before accepting the proposition that American law, laid down from the time of Chief Justice Marshall to the time of Justice Holmes, has been changed, the Banana opinon should be examined. ${ }^{8}$

Blackmer v. United States, 284 U.S. 421, 437 (1932) (refusal by a citizen of the United States to return to the United States to testify); United States v. Curtiss-Wright Export Corp., 299 U.S. 304, 318 (1936) (Joint Resolution expressly directed to prevent United States citizens selling munitions of war in the United States for use in the Chaco war); Skiriotes v. Florida, 313 U.S. 69, 73 (1941) (United States citizen taking commercial sponges from the ocean off the the coast of Florida.)

7. "An Act of Congress ought never to be construed to violate the Law of Nations, if any other possible construction remains," said Chief Justice Marshall in The Schooner Charming Betsy, 2 Cranch 64, 118 (U.S. 1804). And in The Appollon, 9 Wheat. 361, 367 (U.S. 1824), Mr. Justice Story said: "The laws of no nation can justly extend beyond its own territories, except so far as regards its own citizens. They can have no forcc to control the sovereignty or rights of any other nation, within its own jurisdiction. And however general and comprehensive the phrases used in our municipal laws may be, they must always be restricted in construction, to places and persons, unon whom the legislature have authority and jurisdiction."

8. So far as can be determined, an argument based on international law has not been adequately brought forward in any of the pertinent antitrust cases in the past fifteen years. To reserve this question may well have been the express purpase of the Supreme Court in its relevant dictum in Steele v. Bulova Watch Co., 344 U.S. 280, 289 (1952):

"Where, as here, there can be no interference with the sovercignty of another nation, the District Court in exercising its equity powers may command persons properly before it to cease or perform acts outside its territorial jurisdiction."

The Court then admonished us, id. at 289, n.17, to "see British Nylon Spinners, Ltd. v. Imperial Chemical Industries, Ltd., [1952], 2 All Eng. 780, 782 (C.A.)." These words at least reserve the question with which international law is concerned, ris., if there is interference with the sovereignty of another nation, what will be the Court's position?

In Bulova both parties were citizens of the United States. The defendant assembled watch parts and stamped the name "Bulova" upon them, distributing most of them in Mexico and some in the United States. In applying the Lanham Act, on the ground that it reached "all commerce which may lawfully be regulated by Congress," the Court took occasion to say that the Banana case "compels nothing to the contrary." Id. at 288. After distinguishing the Banana decision on the ground that action had been taken by the Costa Rican government, the Court said:

"Viewed in its context, the holding in that case was not meant to confer blanket immunity on trade practices which radiate unlawful consequtences here, merely because they were initiated or consummated outside the territorial limits of the United States. Unlawful effects in this country, absent in the posture of the Banana case before us, are often decisive. . ." Ibid.

As in only too many cases before the Court, the point was barely argued. Outside of a few citations in the respondent's brief, the Court, to the extent that it wished to explore international law, had to do so through its own resources. We are entitled to 
In ascertaining whether or not Justice Holmes misconstrued the Sherman Act, our inquiry may be confined to Section 1 of the Act. This is a reasonable choice because the overwhelming majority of the important cases under the antitrust laws have been those which arose under that Section. And it is that Section which has been principally considered in the important international cases. Section 1 contains three brief concepts, declaring "illegal" (1) "every contract, combination ... or conspiracy" (2) "in restraint of" (3) "trade or commerce with foreign nations." By embracing every "contract, combination ... or conspiracy," Section 1 was designed to refer, and has been authoritatively construed to refer, to every possible agreement, or, indeed, "understanding" among business men, whether written or oral. Agreements may be indicated merely by a nod of the head or by a knowing smile. or, as decided in the famous U.S. Steel case, by silence when business men would understand that silence gives consent. ${ }^{9}$

The second concept- "in restraint of"-is equally wide. The Supreme Court has pointed out that erery event in trade necessarily "restrains," for if $A$ and $C$ are each trying to make a trade with $B$, and $A$ succeeds, $B$ is restrained. Consequently, the Court adopted what is called "the rule of reason"; that is to say, the word "restrain" in the statute must necessarily be construed as being confined only to those acts which "unduly and unreasonably restrain." But the action of these adverbs only emphasis the width of the verb. It follows necessarily that the statute must be applied according to the notions of the judges who apply it and that these notions in turn must conform essentially to the commercial standards of the community in which the judges live. In other words. it simply means that American standards will he applied.

The Sherman Act has been called our charter of freedom for all trade.10 A more correctly descriptive phrase than "antitrust laws" might well be nothing less than "laws governing trade and commerce." True. major sectors of trade and commerce-e.g., railroads, shipping, aviation, public utilities, and agriculture-have been in large part excepted by the Congress from the antitrust laws. The Sherman Act can only apply to residual problems in these "industries," their central problems being regulated by other governmental means. Other sectors of activity-e.g., labor relations-are economic in

presume that on a question of international importance they would not consider that they had foreclosed their judgment against full argument merely because they had given expression to a dictum in Bulloza.

The Banasta case was also referred to in the dissenting opinion of Justices Reed and Douglas, but there was nothing in this dissent that indicated a difference of opinion with the majority. Id. at 290-1. Moreover the dissent said: "The Lanham Act, like the Sherman Act, should be construed to apply only to acts done within the sovercignty of the United States." Id. at 292. This again indicates that the Sherman Act was limited, and that the question considered and decided by the Court in the Buloza case was whether or not the Lanham Act should be similarly "confined."

9. United States v. United States Steel Corp., 223 Fed. 55, 159-60 (D.X.J. 1915).

10. Appalachian Coals, Inc v. United States, 288 U.S. 344, 359 (1933). 
character but not covered by the Sherman Act, because they do not fall within the word "industry." Even many purely "industrial" activities are excepted from the principles of the antitrust laws; for example, the production of oil is regulated by restrictive principles imposed by the states of the Union and supported by a federal compact and statute.

These extensive exceptions governing most of the really basic inclustrial activities-of the type that in many foreign nations are simply nationalizedmight well give us pause as to whether the enthusiasm of public opinion and of the courts for rigorous enforcement of the principles of Adam Smith in all other branches of commerce should not be more tempered. It can hardly be ultimate economic truth that the division is so sharp between those industrial activities in which competitive forces should be closely restricted by the State and those in which competition is required to be of a cut-throat character. We cannot be so surprised, therefore, when we find that foreign nations beg leave to differ with us as to the wisdom of application of the antitrust laws, in all their ferocity, to some of these industries which may happen to be more basic in economics than our Congress or States have yet got around to recognizing.

The third concept in Section 1-"trade or commerce with foreign nations" -is a jurisdictional feature of the statute. The Federal Government had authority to enact, and the courts have authority to enforce, the Sherman Act only because it is within the constitutional delegation of authority "to regulate Commerce with foreign Nations, and among the several States, and with the Indian Tribes." 11 There is a difference in principle between the relation of the Federal Government to interstate commerce and its relation to foreign commerce. The Court has recognized the peculiar and preemptive power of the Executive in foreign affairs. ${ }^{12}$ Underlying this recognition is the fact that foreign affairs involve a whole mass of potential conflicts which are normally settled by diplomacy and ultimately by war, and which are necessarily quite different from the conflicts among the several states of the Union. By parity of reasoning the jurisdictional reach of a legislative enactment applicable to "Commerce with foreign Nations" should be solicitously controlled.

The United States is not compelled by rules of statutory interpretation to assert jurisdiction over acts abroad which have merely "some effects" in this country merely because it asserts jurisdiction over domestic acts which have effects on interstate commerce. The Constitution distinguishes between commerce "with" foreign nations and commerce "among" the several states, and the same distinction is carried into the Sherman Act. A fair construction of the English language might reasonably support a holding that there is a wider compulsion in the power to regulate what occurs "among" domestic sovereignties than there is to regulate what occurs "with" foreign nations.

11. U.S. Const. Art. I, § 8.

12. United States v. Belmont, 301 U.S. 324, 330 (1937). 
There are weighty considerations of historical and juridical importance in the field of foreign affairs that far outweigh the simple process of drawing analogies from experience in domestic affairs. During an earlier period in our national histury, we were as concerned as we are today about our relations with foreign nations. The first generation of the Republic coincided with the period of the Napoleonic wars and their aftermath. Throughout this period the United States was predominantly a commercial navigating nation. The period of the clipper ships carried at least through the second generation an emphasis upon relations with Europe, both in trade and in culture, whether on the part of the navigating States of the North or the cotton exporting States of the South. It was in this atmosphere that Justices Marshall and Story lived and wrote. And the decisions in our highest Court were free of parochialism in this formative period.

After a century of looking predominantly westward, and of turning its back on the foreign world, the United States entered the current period of internationalism. But we wear our internationalism with a difference. The political events which evidenced our awakening to the threat from Hitler's Germany had immediate consequences in the antitrust field. Concomitant to the Neutrality Act of 1940 ("cash and carry") and the Lend Lease Act of 1941 ("all aid to the Allies short of war"), the Government commenced a series of well publicized prosecutions and injunction proceedings aganist German companies. These companies were not then, and of course have never since been, in a position really to defend themselves before our courts on terms of equality with the Department of Justice. Nor was it long before actions were commenced also against companies in allied and neutral countries. After all, there was no distinction in principle, and the anti-cartel crusade was in full swing.

For some years into the post-war period all European companies were in a poor position to defend themselves. The United States was the nation tu whom all European nations were looking for salvation, first by way of defense in a desperate struggle on their doorsteps and later for aid when their economies were disrupted. European governments were in no mood to provide any of their sparse dollar exchange to companies which wished to take legal action of a character which, to timid government officials, appeared to be a contest with the all-powerful Government across the Atlantic. The decade of the 1940's measures the period during which European nations were essentially prostrate. Yet it was precisely during the ' 40 s that antitrust enforcement, alike in war and peace, advanced by leaps and bounds, culminating with the decree of Judge Ryan in the Imperial Chemical Industrics case in 1952, which in turn gave rise to the sharp reaction of the English courts in the Britis/s Nylon Spinners case. The new idea of leadership in international affairs and the ease of its assertion against the comparative weakness of foreign nations, the sense of power here and of acquiescence there, subcunsciously- led us into neglect of the heretofore well-established limitations on sovereignty.

This neglect is evidenced in the assumption of some American lawyers that since federal jurisdiction grows in an expanding field of interstate commerce, 
the same must be true of the utterly different and more sensitive area of international commerce. Contributing to this assumption is the terminology of the American legal profession which refers to events in another state in the same terms as to events abroad; both are said to be "foreign." The corporation at one end of the Hudson Tube is a "foreign corporation" at the other end, and is there governed by "foreign law." How natural, therefore, that American lawyers should have assumed, when suddenly confronted with international conceptions of wide-reaching public import, that they are familiar, from their limited domestic experience, with the authorities necessary to decide them.

Other factors have contributed to our present attitude. The growth of federal power over the states tended to blur the judicial consciousness of territorial boundaries. There was indeed a policy on the part of recent Administrations to appoint judges who would be less inhibited in crossing those boundaries. In seeking qualified appointees for the federal bench, no emphasis was laid on international experience. While a judge can be a fine, honest judge on domestic issues, no doubt, without ever having traveled or studied abroad, it is not surprising that he sometimes falls into error where international comity is concerned.

But the problem is not only, or indeed essentially, a legal one. It is a national problem-the relation of this nation with other nations. In considering whether the United States should cease attempting to impose its antitrust laws upon other peoples, President Eisenhower's Inaugural Address sounds the keynote:

"Honoring the identity and heritage of each nation of the world, we shall never use our strength to try to impress upon another people our own cherished political and economic institutions." 


\section{THE YALE LAW JOURNAL}

EDITORIAL BOARD

Dand R. Hyoe

Editor-in-Chicf

\section{RichaRd A. Sifgal Article and Book Reviezo Editor}

WILLIAM BARONOFF ROBERT WII. BEREND Ruchard K. Berg Múrry David Brochin BARRY R BRYAN Thomas N. Carruthers, Jr. Jeronie A. Cohen Donald J. Cohn LEWTS G. COLE JoHN W. Colleran Willians H. Dearpsey, JK. Russerl C. Dilks David A. Drexlek S. GoRDon ElKINS Kraus EPpler

\author{
Marvin Katz \\ David R. Tillinghast \\ JON R. WALTZ \\ Note and Comment Editors
}

Joseph MI. FietD

BERNARD FinkelsteI:

JosepH B. GLDENHOR:

Alan Gladstone

Howard AlaN Glichstei::

Nornan S. Goldsumte

Harold Grabino

ANNe Gross

Charles S. Haight, Jr.

Elliot Lee Horfarax

Alexander P. Hoffarand

ROBEBT L. LASKY

NoEl ARTOLd Levin

Charles S. Miechem, Jr.

THomas F. NeLson

\section{PAYSON WOLFF Managing Edifor}

Lawance Newsa: Stuakt M. Pales: Alvix H. Scnuluar: JeAN:se RutChIE SRubr Alo:troe Silverusa: Richand S. Sunso:ts Damer AI. Suiges Gorron B. Srivack Mielpin Stal: Stephe: W. TuLIX Grold Walfu: Roges A. Werci PAUL R. WeltcaEK HAROLD M. WVIT Grorae C. Zachari'

Marie ḾcMlamon

Business Secretary

\section{CONTRIBUTORS TO THIS ISSUE}

Fleming James, JR. B.A. 1925, LL.B. 1928, Yale University. Laiayette S. Foster Professor of Law, Yale Law School. Co-author: Szulasan \& Jasres, Cases o: Torrs (2d ed. 1952).

George Winthrop HaIght. B.A. 1928, LL.B. 1931, Yale University. Mfember, New York Bar. Manager of the London legal department of a corporation engaged in internstional commerce.

Willial Divight Whitney. B.A. 1920, Yale University; B.A. Juris. 1923, Osford University; LL.B. 1924, Yale University; M.A. Juris. 1928, Oxford University. Special Assistant to the Attorney-General of the United States, 1926-7. Nfember, New York Bar; Barrister, Inner Temple, London. Mlember of the firm of Cravath, Swaine \& Moore, New York City. 